\title{
Original Research \\ A qualitative study exploring public perceptions on the role of community pharmacists in Dubai
}

\author{
Ibrahim K. RAYES, Mohamed A. HASSALI, Abduelmula R. ABDUELKAREM. \\ Received (first version): 16 -Sep-2013 \\ Accepted: 15-Jan-2014
}

\begin{abstract}
$^{*}$
Background: The role of community pharmacists is very important due to their access to primary care patients and expertise. For this reason, the interaction level between pharmacists and patients should be optimized to ensure enhanced delivery of pharmacy services.

Objective: To gauge perceptions and expectations of the public on the role of community pharmacists in Dubai, United Arab Emirates (UAE).

Methods: Twenty five individuals were invited to participate in 4 separate focus group discussions. Individuals came from different racial groups and socioeconomic backgrounds. Interviews were audio-recorded and transcribed. Using thematic analysis, two reviewers coded all transcripts to identify emerging themes.

Appropriate measures were taken to ensure study rigor and validity.

Results: All facilitators and barriers that were identified were grouped into 5 distinct themes. The pharmacist as a healthcare professional in the public mind was the most prominent theme that was discussed in all 4 focus groups. Other themes identified were, in decreasing order of prevalence, psychological perceptions towards pharmacists, important determinants of a pharmacist, the pharmacy as a unique healthcare provider, and control over pharmacies by health authorities.

Conclusions: This study provided insight into the way that the public looks at the role of community pharmacists in Dubai. Determinants that influence their perception are the media, health authorities, pharmacist's knowledge level, attire, nationality, age, and pharmacy location.
\end{abstract}

Keywords: Community Pharmacy Services; Pharmacies; Professional Practice; Consumer Satisfaction; Focus Groups; United Arab Emirates

\section{INTRODUCTION}

Pharmaceutical care has passed through 3 major redefinitions over the last 2 decades. ${ }^{1}$ The "compounding" era was replaced by the "count-andpour" era which was, over a period of time, overtaken by the clinical pharmacy movement. ${ }^{2}$ Most recently, pharmaceutical care has adopted a new set of assumptions, concepts, and values that have made the pharmacy practice patient-centered rather than merely product-oriented. ${ }^{3-5}$

\footnotetext{
*Ibrahim Khalid RAYES. BPharm, MBA. Discipline of Social and Administrative Pharmacy, School of Pharmaceutical Sciences, Universiti Sains Malaysia. Penang (Malaysia).

Mohamed Azmi HASSALI. BPharm (Hons), MPharm, PhD. Associate Professor, Discipline of Social and Administrative Pharmacy, School of Pharmaceutical Sciences, Universiti Sains Malaysia. Penang (Malaysia). Abduelmula R. ABDUELKAREM. BPharm, MPhil (Clinical Pharmacy), PhD. Associate Professor, Department of Pharmacy Practice and Pharmacotherapeutics, College of Pharmacy, University of Sharjah. Sharjah (United Arab Emirates).
}

Pharmacists have an important role in healthcare delivery because of their expertise and location within communities that gives them close proximity to patients, such that they are sometimes the first respondents in the healthcare system. ${ }^{6}$ This interaction between patients and pharmacists has been extensively studied in many developed countries and values like patient satisfaction with pharmaceutical care type or with specific disease management services were thoroughly assessed. ${ }^{7-}$ 10 However, these values are often not generalizable to developing countries such as the Middle East where the first priority is still traditional pharmacy practice. ${ }^{11}$ While there have been some efforts to gauge patients' satisfaction level in some Middle East countries ${ }^{12-14}$, there have not been many research papers that explored concepts such as public perceptions and expectations towards the role of community pharmacists in Dubai, United Arab Emirates (UAE). UAE is one of rich Gulf Cooperation Council countries in the Middle East and has gross domestic product (GDP), per capita, of around USD52,435. ${ }^{15,16}$ The UAE has a diverse and a fast expanding population which was estimated to break the mark of 8 million in $2010 .{ }^{10}$ However, UAE nationals are considerably few compared to expatriates (other Arab countries, Iran, South East and South Asia) who constitute approximately $88.5 \%$ of the total population. ${ }^{17}$ Dubai is the economic capital of the country where the healthcare system is well developed. It is controlled by a unique governmental body called Dubai Health Authority. This Authority is responsible of licensing medical professionals as well as controlling medical and pharmaceutical organizations within the boundaries of Dubai.

The objective of this study is to better understand the way the public perceives pharmacists as a part of the healthcare professionals' team in Dubai, UAE in order to improve community pharmacy services and image among the general public in Dubai.

\section{METHODS}

This paper presents an in-depth, phenomenological study exploring the perceptions and expectations of the general public on the role of community pharmacists in Dubai, UAE. It is a part of a larger qualitative as well as quantitative study which is done to explore the perceptions of general public on the role of community pharmacists in Dubai. Semistructured focus group interviews were conducted with a convenience sample of 25 participants from different geographic settings, varying age and gender, and different education levels within the boundaries of Dubai. The source of information 
about potential participants was gathered from the data base of Ajman University of Science and Technology. A total number of 143 Students and exstudents were approached by emails asking them to participate in open discussion about their perceptions on the role of pharmacists in Dubai. The age range of participants was 19 to 48 years old.

Four different focus groups were separately held in a private rented hall in Dubai. The mean age ranges in the focus groups from 1 to 4 were $27,26,28$, and 37 years old respectively. The fact that most of participants were young can be justified by taking into consideration that $50.74 \%$ of Dubai population's age range between 20 and 34 years old. ${ }^{18}$ The discussions took an average of 1 to 1.5 hours and were conducted by a trained and well experienced interviewer (IKR). Appropriate probing questions were used when necessary to get more in-depth views from the participants (Interested readers may obtain a copy of the question guide and probes used). ${ }^{19}$ To obtain more complete ideas; participants were given freedom to express additional views on the topic at the end of the group discussion session. Group discussions were digitally recorded, transcribed verbatim, and the transcripts were supplemented with field notes that were taken during the discussions and immediately after. Two of the authors (IKR and ARA) listened to all audio recordings and IKR analyzed the transcripts for relevant content and themes. The thematic framework contained dominant themes that were refined as associations were made in order to provide explanations for findings. ${ }^{20,21}$

This study was approved by the Ajman University of Science and Technology Human Research Ethics Committee in the UAE. The study was carried out over a period of 1 month (April 01, 2013 to April 30, 2013) with an interval of 1 week between different focus groups.

\section{RESULTS}

Out of 143 individuals who were invited to attend the focus groups, 25 agreed to participate. They were randomly divided into 4 separate groups. The demographic characteristics of the pooled participants are summarized in Table 1 . The main themes identified were related to pharmacists in the public mind, psychological perceptions, determinants of pharmacists, effect of the pharmacy as a healthcare unit on the pharmacist, and control over pharmacies.

Table 2 outlines the various themes and subthemes along with examples of data excerpts. The following description presents all 5 themes in decreasing order of prevalence. The frequency of participant commentary on factors and the number of codes collated to form themes are included to give readers a sense of the predominant factors that were identified during analysis.

\section{Theme 1: Pharmacist as a Healthcare Professional in Public Minds}

The most commonly identified theme was concerned with perceptions of the general public on the role of community pharmacists in Dubai. This was the only theme that was identified in all focus group discussions and a total of 35 codes were organized under this theme. The codes were further organized into two sub-themes: "who is a pharmacist to the general public?" and "reasons to seek pharmacists' consultations." Twenty-two out of the 25 participants defined a pharmacist as a medicine seller and prescriber. At a glance, it is interesting to add that 14 participants approached pharmacies in cases of minor illness, difficulties in reaching their physicians, and/or difficulties in using their medicines.

\section{Theme 2: Psychological Perceptions Towards Pharmacists}

The second predominant theme identified the effect of the following psychological determinants on the perceptions of the public towards trusting pharmacists' advice: perceptions towards the knowledge level of pharmacists, trust level of the public, and respect level of the public. Twenty-one participants were found to have a certain level of belief that a pharmacist in Dubai has enough level of knowledge of medicines which makes him/her a trustworthy healthcare service provider. The rest of the participants (4) assumed that pharmacists in Dubai have no knowledge and that they are only medicine sellers.

\section{Theme 3: Important Determinants of a Pharmacist}

Seventeen participants interacted on some important aspects and characteristics of pharmacists that further increase or decrease the worthiness of their profession in the eyes of the public. Three codes were generated accordingly: the effect of a pharmacist's attire, nationality, and age. Eight participants felt that the outer appearance of the pharmacist was not important. Others (17) saw a positive influence of wearing a white coat and/or a tie compared to only wearing a shirt or T-shirt. Interestingly, 16 participants expressed some concerns about pharmacists' origins. They had some difficulties communicating or trusting certain nationalities. Of these, 13 added that the age of the pharmacist is an important determinant of a good pharmacist, so that; the older the pharmacist, the more experienced he/she is.

\begin{tabular}{|l|c|c|c|c|}
\hline Table 1. Demographic details of focus group participants. & Focus Group 3 & Focus Group 4 \\
\hline Num. of participants who attended & Focus Group 1 & Focus Group 2 & 7 & 6 \\
\hline UAE nationals & 6 & 6 & 3 & 2 \\
\hline Expatriates & 2 & 2 & 4 & 4 \\
\hline Participant code & 4 & 4 & P13-P19 & P20-P25 \\
\hline Mean age (years) & P1-P6 & P7-P12 & 28 & 37 \\
\hline Range & 27 & 26 & $20-36$ & $31-48$ \\
\hline
\end{tabular}




\begin{tabular}{|c|c|}
\hline Theme/sub-theme & Example \\
\hline \multicolumn{2}{|c|}{ Theme 1: Pharmacist as a healthcare professional in the public mind $(8,35)$ * } \\
\hline Sub-theme 1: Pharmacist definition $(10,18)$ & $\begin{array}{l}\text { "To me; pharmacist is a medicine prescriber, he is taking care of } \\
\text { medicines' availability. In addition, he can help in getting cured } \\
\text { from minor illness." }\end{array}$ \\
\hline Sub-theme 2 : Consultation reasons $(4,14)$ & $\begin{array}{l}\text { "I approach the pharmacy when I have a problem and I can not } \\
\text { reach to my doctor, or when I do not know details of my medicine } \\
\text { usage." }\end{array}$ \\
\hline \multicolumn{2}{|c|}{ Theme 2: Psychological perceptions towards pharmacists $(22,24)$} \\
\hline $\begin{array}{l}\text { Sub-theme 1: Perceptions towards knowledge level of } \\
\text { pharmacists }(5,11)\end{array}$ & $\begin{array}{l}\text { "I believe that the pharmacist have enough knowledge about } \\
\text { medicines because he is a specialized person." } \\
\text { "The pharmacist has no knowledge like doctors. They only sell } \\
\text { drugs." }\end{array}$ \\
\hline \multirow[t]{2}{*}{ Sub-theme 2: Trust level of the public $(23,25)$} & $\begin{array}{l}\text { "I trust the pharmacist to some extent. Some of the times } \\
\text { pharmacists want to sell medicines like any other sales people." }\end{array}$ \\
\hline & "I definitely respect pharmacists because they take care of us." \\
\hline \multicolumn{2}{|l|}{ Theme 3: Important determinants of a pharmacist $(8,17)$} \\
\hline \multirow[t]{2}{*}{ Sub-theme 1: Attire $(6,13)$} & $\begin{array}{l}\text { "The trust level in my mind is increasing when I see a pharmacist } \\
\text { wearing respectful clothing. This will ensure respecting the place } \\
\text { the pharmacist is working in as well as the patient he is taking } \\
\text { care of." }\end{array}$ \\
\hline & $\begin{array}{l}\text { "There is no effect whether the pharmacist is wearing a tie or as } \\
\text { long as he provides proper consultation." }\end{array}$ \\
\hline Sub-theme 2: Nationality $(16,17)$ & $\begin{array}{l}\text { "Yes, pharmacist's nationality is an important matter. Some } \\
\text { nationalities have some difficulties in delivering information about } \\
\text { medicines usage." }\end{array}$ \\
\hline Sub-theme 3: Age $(12,16)$ & "The older the pharmacist, the more experience he has." \\
\hline \multicolumn{2}{|l|}{ Theme 4: Effect of the pharmacy on the pharmacist $(4,10)$} \\
\hline Sub-theme 1: Pharmacy location $(3,7)$ & $\begin{array}{l}\text { "I don't like to go to a pharmacy that have no enough parking } \\
\text { space, or always crowded." }\end{array}$ \\
\hline Sub-theme 2: Decoration $(4,5)$ & $\begin{array}{l}\text { "There are many factors that bring me to the same pharmacy } \\
\text { again and again. Some of them are fancy shelves' arrangement, } \\
\text { Nice decoration, and bright lights" }\end{array}$ \\
\hline \multicolumn{2}{|l|}{ Theme 5: Control over pharmacies $(5,10)$} \\
\hline Sub-theme 1: Control on medicines' retail prices $(5,9)$ & $\begin{array}{l}\text { "Ministry of Health and medical agents together control prices of } \\
\text { medicines but I think that not all pharmacists follow the fixed } \\
\text { prices as some of them give extra discounts when asked." }\end{array}$ \\
\hline $\begin{array}{l}\text { Sub-theme 2: Regulating authorities and their role to } \\
\text { control pharmacies }(2,7)\end{array}$ & $\begin{array}{l}\text { "Control over pharmacies must be enhanced by authorities as } \\
\text { there are some pharmacists who sell duplicate medicines and play } \\
\text { over the prices which - I think - should be constant all over the } \\
\text { UAE." }\end{array}$ \\
\hline e first number in parentheses indicates the nt & articipants who commented on that theme/code and the second \\
\hline
\end{tabular}

Theme 4: The Effect of the Pharmacy on the Pharmacist

The pharmacy is a healthcare provider that has, due to its location within communities, a unique power to sometimes operate as the first responder in the healthcare system. The pharmacists and their behaviors are not the only factors that affect the perception of the public on the role that they are expected to play. The location of the pharmacy is may add either comfort or frustration to the patient experience. This was disclosed by 7 participants who commented that decoration, bright lights, and space play a crucial role in deciding which pharmacy to visit.

\section{Theme 5: Control over Pharmacies}

Two sub-themes were extracted from the focus group discussions surrounding control over pharmacies. The first was related to the control over the retail prices of medicines. Most of the participants (21) stated that the Ministry of Health $(\mathrm{MOH})$, along with the assigned medical agents, is responsible for monitoring and fixing medicines' retail prices. Despite this fact, 7 participants showed some doubt about the level of control by the regulating authorities on retail pharmacies. They believed that some pharmacists sell duplicate drugs and others do not follow the prices of drugs fixed by the $\mathrm{MOH}$.

\section{DISCUSSION}

The findings of this study developed a defining standard for the perceptions of the general public on the role of community pharmacists in Dubai, UAE. As such, it was the first time the term "pharmacist" was explored in a discussion session in Dubai. Interestingly, 10 participants commented that a pharmacist is a medicine seller. This phenomenon 
of under-estimation must be further studied in future to know its relation with factors that might affect the perception of public on the role of community pharmacists in Dubai. Some of the factors that can be studied are the effect of media, the patient's background, previous experience, and/or the pharmacist's interpersonal skills. ${ }^{22}$ In one similar study that was conducted in Australia, community pharmacists' roles perceived by public were similar to their colleagues in Dubai in many aspects, with minor differences like an elevated trust level in Australia compared to Dubai. ${ }^{23}$ Larger scale quantitative studies must measure the extent to which the public trusts and respects pharmacists' instructions and guidance in Dubai, taking into consideration that most of the registered pharmacists in the UAE are expatriates with different levels of background, experience, and training. ${ }^{24,25}$

As mentioned in theme 3 , there are other factors that further contribute to the public's acceptance of the role of community pharmacists in Dubai. Pharmacists wearing shirts have more acceptance than pharmacists wearing t-shirts. In the same context, pharmacists wearing a tie and a white coat added more respect in their patients' minds compared to wearing a white coat without a tie. It should be mentioned that the attire of pharmacists has been extensively studied elsewhere in the literature. ${ }^{26}$ Moreover, the pharmacist's nationality was important to 9 participants. They argued that pharmacists coming from certain nationalities might have a language barrier that could result in dispensing or prescribing wrong or unnecessary medications due to miscommunication or their business orientation. This can be the situation in many Gulf Cooperation Council countries where most of the registered pharmacists are expatriates. ${ }^{27,28}$ In addition, more than half of the participants (13) pointed out that the older the pharmacist, the more they granted trust to him/her.

Moreover, the pharmacy as a drug shop was an additional determinant that could play a crucial role in shaping the relationship between pharmacists and their patients. Factors such as the ease with which the neighborhood pharmacy could be reached and adequate space and light inside the pharmacy were mentioned about 7 times. The least common theme that arose illustrated public perception of the extent to which health authorities control and regulate private pharmacies in Dubai.

The previous points suggest that the general public perceives community pharmacists in Dubai positively. Factors that play roles in building an image of pharmacists in Dubai include health authorities, pharmacist's knowledge level, attire, nationality, age, and pharmacy location.

\section{Limitations of the study}

An often cited limitation of qualitative studies is the inability to generalize to a larger population. ${ }^{29}$ This study was conducted only with 25 participants in Dubai and thus the findings cannot be generalized to the public in the UAE. However, the opinions gathered from all the focus groups conducted in the present study will be useful to enrich our large quantitative survey among the public in Dubai we are currently conducting.

\section{CONCLUSIONS}

In conclusion, this study provided insight into the way the public perceives community pharmacists in Dubai, UAE. Our findings can be used to promote discussion in the profession and with stakeholders about the future role of the community pharmacist in patient care in Dubai. Future studies should focus on providing significant data about the perception of the general public on the expected enhanced role of community pharmacists in the country.

\section{CONFLICT OF INTEREST}

There are no conflicts of interest.

Funding Information: This study was supported by a research grant from Universiti Sains Malaysia.

\section{ESTUDIO CUALITATIVO DE EXPLORACIÓN DE LAS PERCEPCIONES DEL PÚBLICO SOBRE EL PAPEL DEL FARMACÉUTICO COMUNITARIO EN DUBÁI}

\section{RESUMEN}

Antecedentes: El papel de los farmacéuticos comunitarios es muy importante debido a su acceso a los pacientes de atención primaria y sus conocimientos. Por esta razón, debería optimizarse el nivel de interacción entre farmacéuticos y sus pacientes para asegurar la provisión de servicios farmacéuticos.

Objetivo: Medir las percepciones y expectativas del público sobre el papel de los farmacéuticos comunitarios en Dubái, Emiratos Árabes Unidos (UAE).

Métodos: Se invitó a 25 individuos a participan en 4 discusiones de grupos focales. Los individuos venían de diferentes grupos raciales y antecedentes socio económicos. Las entrevistas se grabaron y se transcribieron. Dos revisores codificaron todas las transcripciones, usando un análisis temático, para identificar los temas emergentes. Se tomaron las medidas apropiadas para asegurar el rigor y la validez del estudio. Resultados: Todos las barreras y facilitadores identificados se agruparon en 5 temas distintos. El farmacéutico como profesional de la salud en la mente del público fue el tema más prominente que se discutió en los 4 grupos focales. Otros temas identificados fueron, en orden decreciente de aparición, percepciones psicológicas sobre el farmacéutico, determinantes importantes de un farmacéutico, la farmacia como local de salud único, y el control de las farmacias por las autoridades sanitarias.

Conclusiones: Este estudio proporcionó una visión sobre el modo en que el público ve el papel del farmacéutico comunitario en Dubái. Los determinantes que influencian su percepción son, los medios de difusión masiva, autoridades sanitarias, nivel de conocimientos del farmacéutico, vestimenta, nacionalidad, edad, y la localización de la farmacia.

Palabras clave: Servicios de Farmacias Comunitarias; Farmacias; Práctica Profesional; Satisfacción del Consumidos; Grupos Focales; Emiratos Árabes Unidos 


\section{References}

1. Higby GJ. American pharmacy in the twentieth century. Am J Pharm Educ. 1997;54:1805-1815.

2. Clark BE, Mount JK. Pharmacy service orientation: a measure of organizational culture in pharmacy practice sites. Res Social Adm Pharm. 2006;2(1):110-128.

3. Anderson S. Making medicines: a brief history of pharmacy and pharmaceuticals. London, UK: Pharmaceutical Press:; 2005.

4. Peterson AM, Kelly WN. Managing pharmacy practice: principles, strategies, and systems. Boca Raton, FL: CRC Press:; 2004.

5. Niquille A, Lattmann C, Bugnon O. Medication reviews led by community pharmacists in Switzerland: a qualitative survey to evaluate barriers and facilitators. Pharm Pract (Granada). 2010;8(1):35-42.

6. Smith F. Private local pharmacies in low-and-middle income countries: a review of interventions to enhance their role in public health. Trop Med Int Health. 2009;14(3):362-372. doi: 10.1111/j.1365-3156.2009.02232.x

7. Pascoe GC. Patient satisfaction in primary health care: a literature review and analysis. Eval Program Plann. 1983;6(34):185-210.

8. Marquis MS, Davies AR, Ware JE Jr. Patient satisfaction and change in medical care provider: a longitudinal study. Med Care. 1983;21(8):821-829.

9. Zastowny TR, Roghmann KJ, Cafferata GL. Patient satisfaction and the use of health services: explorations in causality. Med Care. 1989;27(7):705-723.

10. Gourley GK, Gourley DR, La Monica Rigolosi E, Reed P, Solomon DK, Washington E. Development and validation of the pharmaceutical care satisfaction questionnaire. Am J Manag Care. 2001;7(5):461-466.

11. Hasan S, Sulieman H, Stewart K, Chapman CB, Hasan MY, Kong DC. Assessing patient satisfaction with community pharmacy in the UAE using a newly-validated tool. Res Social Adm Pharm. 2013;9(6):841-850. doi: 10.1016/j.sapharm.2012.10.002

12. Khdour MR, Hallak HO. Societal perspectives on community pharmacy services in WestBank - Palestine. Pharm Pract (Granada). 2012;10(1):17-24.

13. Bawazir SA. Consumer attitudes towards community pharmacy services in Saudi Arabia. Int J Pharm Pract. 2004;12(2):83-89.

14. El Hajj MS, Salem S, Mansoor H. Public's attitudes towards community pharmacy in Qatar: a pilot study. Patient Prefer Adherence. 2011;5:405-422. doi: 10.2147/PPA.S22117

15. Wikipedia. United Arab Emirates 2013. Available from: http://en.wikipedia.org/wiki/United_Arab_Emirates (Accessed 2013 Nov 22).

16. United Nations Development Program 2011. International Human Development Indicators, Country Profile: UAE 2011. Available from: http://hdrstats.undp.org/en/countries/profiles/ARE.html (Accessed 2013 Nov 22).

17. National Bureau of Statistics - United Arab Emirates 2010. Population Estimates 2006-2010 [Internet]. http://www.uaestatistics.gov.ae/ReportDetailsEnglish/tabid/121/Default.aspx?Itemld=1914\&PTID=104\&Menuld=1 (Accessed 2013 Nov 22).

18. Dubai Statistics Centre. Population and vital statistics 2012. [Available from: http://dsc.gov.ae/EN/Themes/Pages/Reports.aspx?Topicld=23 (Accessed 2013 Nov 21).

19. Berg BL. Qualitative research methods for social sciences. 5th ed. Boston, MA: Allyn \& Bacon; 1998.

20. Mays N, Pope C. Qualitative research: rigour and qualitative research. BMJ. 1995;311(6998):182-184.

21. Pope C, Ziebland S, Mays N. Qualitative research in health care. Analysing qualitative data. BMJ. 2000;320(7227):114116.

22. Hasan S, Sulieman H, Chapman C, Stewart K, Kong DC. Community pharmacy in the United Arab Emirates: characteristics and workforce issues. Int J Pharm Pract. 2011;19(6):392-399. doi: 10.1111/j.2042-7174.2011.00134.x

23. McMillan SS, Wheeler AJ, Sav A, King MA, Whitty JA, Kendall E, Kelly F. Community pharmacy in Australia: a health hub destination of the future. Res Social Adm Pharm. 2013;9(6):863-875. doi: 10.1016/j.sapharm.2012.11.003

24. Ministry of Health - UAE 2003. Guidelines and minimum standards for good pharmacy practice in UAE pharmacies. Available from: http://www.cpd-pharma.ae/index.php?option=com_phocadownload\& view=category\&download=76:ministry-of-health-guideline-and-minimum-standards-for-good-pharmacy-practice-gppversion-1-2003\&id=2: moh-policies-and-circulars\&ltemid=78 (Accessed 2013 Jun 30).

25. Ministry of Health - UAE 2011. Drug Registration and Control Administration Statistics 2010-2011.

26. Khanfar NM, Zapantis A, Alkhateeb FM, Clauson KA, Beckey C. Patient attitudes toward community pharmacist attire. J Pharm Pract. 2013;26(4):442-447. doi: 10.1177/0897190012465956

27. Kheir N, Zaidan M, Younes H, El Hajj M, Wilbur K, Jewesson PJ. Pharmacy education and practice in 13 Middle Eastern countries. Am J Pharm Educ. 2008;72(6):133.

28. Kheir N, Fahey M. Pharmacy practice in Qatar: challenges and opportunities. South Med Rev. 2011;4(2):92-96. doi: 10.5655/smr.v4i2.1007

29. Creswell JW, Fetters MD, Ivankova NV. Designing a mixed methods study in primary care. Ann Fam Med. 2004;2(1):712. 